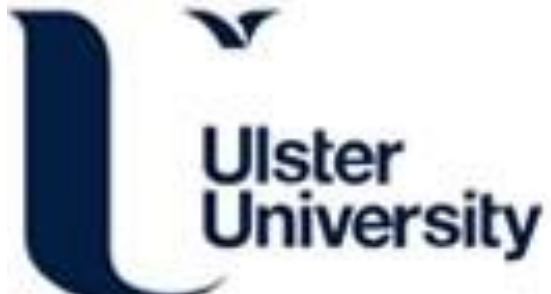

Local government in Northern Ireland: Emerging from the bearpit of sectarianism

Knox, C. (1998). Local government in Northern Ireland: Emerging from the bearpit of sectarianism. Local Government Studies, 24(3), 1-13.

Link to publication record in Ulster University Research Portal

Published in:

Local Government Studies

Publication Status:

Published (in print/issue): 01/01/1998

\section{Document Version}

Publisher's PDF, also known as Version of record

\section{General rights}

Copyright for the publications made accessible via Ulster University's Research Portal is retained by the author(s) and / or other copyright owners and it is a condition of accessing these publications that users recognise and abide by the legal requirements associated with these rights.

\section{Take down policy}

The Research Portal is Ulster University's institutional repository that provides access to Ulster's research outputs. Every effort has been made to ensure that content in the Research Portal does not infringe any person's rights, or applicable UK laws. If you discover content in the Research Portal that you believe breaches copyright or violates any law, please contact pure-support@ulster.ac.uk. 
This article was downloaded by: [Swets Content Distribution]

On: 30 March 2010

Access details: Access Details: [subscription number 912280237]

Publisher Routledge

Informa Ltd Registered in England and Wales Registered Number: 1072954 Registered office: Mortimer House, 3741 Mortimer Street, London W1T 3JH, UK

Local Government Studies

R poutldede

\section{Local Government Studies}

Publication details, including instructions for authors and subscription information: http://www.informaworld.com/smpp/title content=t713673447

\section{Local government in Northern Ireland: Emerging from the Bearpit of sectarianism?}

Colin Knox ${ }^{\text {a }}$

${ }^{\text {a }}$ Professor of Public Policy in the School of Public Policy, Economics and Law, University of Ulster,

To cite this Article Knox, Colin(1998) 'Local government in Northern Ireland: Emerging from the Bearpit of sectarianism?', Local Government Studies, 24: 3, $1-13$

To link to this Article: DOI: 10.1080/03003939808433915

URL: http://dx.doi.org/10.1080/03003939808433915

\section{PLEASE SCROLL DOWN FOR ARTICLE}

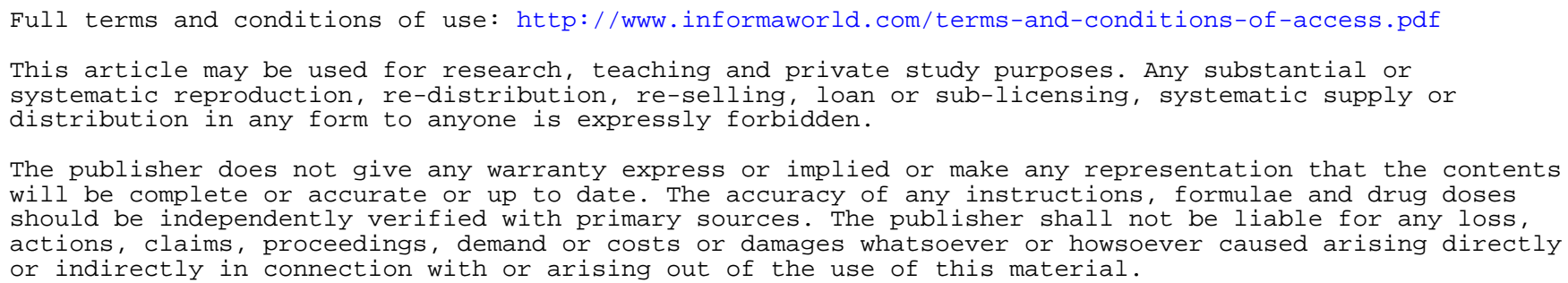




\title{
Local Government in Northern Ireland: Emerging from the Bearpit of Sectarianism?
}

\author{
COLIN KNOX
}

The ongoing multi-party talks on the future constitutional arrangements for Northern Ireland overshadow much of the dayto-day business of local government. Yet there are signs that councils, despite their relatively minor functions, are emerging as important cross-community players in Northern Ireland. This paper examines the key events in local government since 1973, the main issues currently facing councils and offers a prospective assessment of their future role.

Northern Ireland has moved from a situation where there were too many democratic bodies lacking the necessary checks and balances to prevent them from being abused by the elected representatives, to a position where local government structures are largely powerless. What is now lacking are the necessary checks and balances to prevent abuse by the minister's nominees, by bureaucrats and indeed by ministers, none of whom are answerable to the Northern Ireland electorate ... a political vacuum. I want to see local government filling the vacuum in Northern Ireland. (Ken Maginnis MP, Ulster Unionist Party, 1992:100)

Giving some councils restored powers would be like inviting Erich Honeker back to implement the reform programme in East Germany. (Alban Maginness, SDLP Mayor of Belfast City Council, 1990:4)

These two juxtapositions best illustrate the different party political positions on local government in Northern Ireland. Its relatively minor functional role belies its symbolic importance as an elected forum which has survived intact when one political initiative after another has foundered at the macrolevel.

Local councils have three main roles: an executive role in which they provide certain regulatory services (for example, building regulations, environmental health, licensing of dance halls, cinemas) and the provision of a limited range of functions such as street cleaning, refuse collection, 
cemeteries and crematoria, recreation and tourist amenities and economic development; a representative role where members are nominated to serve on area boards (for example, education and library boards); and a consultative role where councils' views are sought on centrally provided services such as planning, roads, water and housing.

These seemingly innocuous roles have attracted a degree of criticism. The absence of major functional responsibilities, combined with no regional tier of government, has turned council chambers into a forum for occasional vitriolic and sectarian debate on constitutional and security issues well beyond their remit. By the same token, there is some doubt about the calibre of councillor attracted to a relatively powerless body. From the councils' perspective there is growing unease that their representative role is being eroded (for example, removal of councillors from health boards) under restructuring of central services. An ongoing problem is that government departments and agencies, responsible for providing central services in council areas, treat consultation as a token gesture, at best, or a derisory intervention by councillors with narrow parochial interests, at worst.

A discussion on the role of local government within the overall public administration system in Northern Ireland may seem rather academic given its minor functions. Estimated net spending by councils in 1997/98, for example, amounts to $£ 230 \mathrm{~m}$, approximately 2.7 per cent (Department of the Environment (NI), 1997) out of a Northern Ireland public expenditure budget of $£ 9$ billion. Yet the study of local authorities is important for other reasons. First, whatever form of political accommodation is reached during the ongoing multi-party talks, a future restructuring of the various tiers of government is inevitable and will involve a reassessment of the role of councils. Second, in the absence of any devolved government, councillors are the most accessible source for constituents with concerns about centrally provided services (housing, planning and social security in particular). Third, councils employ about 9,000 people in an economy noted for its high level of unemployment. It is for these reasons that we consider local government in some detail. Our discussions are structured in three parts:

(a) political milestones - an overview of key events in local government since reorganisation in 1973;

(b) administrative realities - an examination of the main issues facing councils at present;

(c) future possibilities - a prospective assessment of local government. 


\section{POLITICAL MILESTONES}

The present system of local government in Northern Ireland is based upon recommendations contained in the Report of the Review Body on Local Government in Northern Ireland (Macrory Report of 1970). The report was the final outcome of pressure to reform local government in the 1960s based on two quite distinct but complementary sources. First, the Northern Ireland Government at Stormont undertook a campaign to modernise local government (beginning in March 1966 - parallel reforms were afoot in Great Britain: Redcliffe-Maud, 1969 and Wheatley, 1972) and remedy its defects and, second, there was dissatisfaction with its performance at a political level. The main administrative defect was the large number of small local authorities which existed with a small rate base, and hence limited financial resources ( 73 elected councils for 1.5 million population). The key political defects were grievances expressed by the minority community over religious discrimination by some local authorities in employment and housing, a motivating factor behind the civil rights protests in 1968 and subsequent outbreak of disturbance (Whyte, 1990). In the wake of considerable violence, housing was removed from the remit of local government which, to a large extent, dictated future administrative reforms. The Macrory Report divided services into regional (requiring large administrative units) and district (suitable for small areas) services. The Stormont Parliament would take responsibility for regional services and 26 councils would administer district services (the influence here was the Wheatley Commission on Scottish local government). The recommendations of the report were overtaken, however, by the abolition of Stormont in 1972 and responsibility for regional services now rests with the British government working administratively through the Northern Ireland Office - direct rule.

Local government in Northern Ireland therefore evolved from the turmoil of the early 1970s against a background of special circumstances which the Macrory Review Body felt were crucial factors in their proposals. The existence of a regional government at Stormont as a sine qua non in any future administrative structure underpinned the recommendations. Its abolition embittered Unionists and, in their view, effectively destroyed local democratic institutions. The absence of a regional tier is referred to as the 'Macrory Gap', something of a misnomer since he was not responsible for it and argued later that it made a nonsense of his proposals (Fitzgerald, 1978).

Three issues of political significance are worthy of discussion since local government emerged in its reorganised form in October 1973: the election of Sinn Fein to local councils; the Unionist protest campaign against the 
Anglo-Irish Agreement and; the development of 'responsibility sharing' in councils.

In 1985 Sinn Fein contested council elections for the first time and secured 59 seats (out of 566), ${ }^{1} 11.8$ per cent of the vote (Knox, 1990). Although they had contested the Assembly, Westminster and European elections of October 1982, June 1983 and June 1984, respectively, their presence in council chambers was anathema to Unionists. Both Unionist parties (DUP and UUP) pledged in election campaigns to 'smash Sinn Fein' and subsequently employed tactics to isolate their councillors by excluding them from committees and preventing them from speaking, where possible (Connolly and Knox, 1988). These tactics were legally challenged and found to be unlawful and void by the High Court. Further attempts to exclude Sinn Fein by demanding that councillors sign a declaration against violence were also challenged by a judicial review, and again Unionists were defeated. Despite continuous disruptions in council chambers, with occasional fist-fights breaking out, the government refused to proscribe Sinn Fein in response to Unionist pressure. At the same time, government ministers would not receive delegations or correspond personally with Sinn Fein members - perceived as double standards by Unionists. The AngloIrish Agreement of November 1985 ushered in a new wave of protest.

Despite government assurances to the contrary, Unionists viewed the Anglo-Irish Agreement as thinly veiled joint sovereignty over the Province by Dublin and London. Their burgeoning local government protest against Sinn Fein was superseded by a campaign of Unionist opposition against a 'sell-out' to Dublin. Eighteen Unionist-controlled councils adopted a policy of adjourning all council meetings and refusing to strike a district rate. They argued that to administer local government was to give tacit support to the London-Dublin partnership (Connolly and Knox, 1988). The decision to suspend meetings and delegate business to council officials was tested in court and, once again, Unionists were defeated. Faced with Unionist recalcitrance over the affair, the minister took new powers to appoint a commissioner and empower council officials to carry out council functions. Belfast and Castlereagh Councils, at the forefront of the protest campaign, remained defiant despite legal contempt proceedings against them on the policy of adjournment, and eventually the government stepped in to maintain essential services. Yet cracks began to appear in the protest campaign. A mass resignation proposal of all UUP and DUP councillors was rejected, some local authorities met to strike a rate for the financial year $1987 / 88$, and accusations abounded of surreptitious business taking place in some Unionist councils. The protest campaign against the Anglo-Irish Agreement at local government level was proving counter-productive. Services continued to be provided amidst fears that Nationalist councils 
were gaining more resources through regular ministerial contacts. The protest withered away to an inauspicious end.

The local government elections of 1989 marked a turning point in council chambers, with a degree of moderation not unrelated to the decline in representation from the political extremes. From this more stable political context an experiment in 'responsibility sharing' developed (this term evolved in deference to Unionist sensitivities over 'power sharing'). Dungannon District Council is credited with leading the way in rotating the council chair between the two main political parties, the SDLP and UUP. ${ }^{2}$ In addition, the Enniskillen bombing of November 1987 appears to have had a profound impact upon local politicians. One observer noted that councillors 'felt the need to bring an end to sterile adversarial politics ... and found in their opposition to political violence more in common than they had previously recognised' (Beirne, 1993:7). In the wake of the 1989 local government elections, 11 local authorities appointed mayors/chairs and deputies from both political traditions. The power-sharing trend continued after the 1993 local government elections and there are encouraging signs that a climate of accommodation now exists in councils, conspicuously absent at the macro-level. Even the more tempestuous councils (for example, Belfast, Craigavon) can now boast power-sharing arrangements. The 1997 local government elections produced Belfast's first nationalist Lord Mayor in its 150-year history and 12 councils, mainly nationalist controlled or hung, currently (1997/98) operate power-sharing arrangements.

\section{ADMINISTRATIVE REALITIES}

By its nature a cursory examination of the main issues facing local government at present must be selective. Four quite distinct areas have been chosen to represent the breadth of topical issues which face councils; economic development, community relations, compulsory competitive tendering/'best value' and local government finance. These are discussed in order.

\section{Economic Development}

Until 1992, local authorities were relatively small-part players in the field of economic development. Their involvement was limited to making contributions to any voluntary body which developed trade, industry and commerce in their area (section 107, Local Government Act 1972) or, more generally, for furthering 'the interests of the council, its district or inhabitants' (section 115, Local Government Act 1972). Total payments were limited to $3 p$ in the pound on the rateable value of the district. 
Key government agencies involved in this function are the Local Enterprise Development Unit (LEDU) and the Industrial Development Board (IDB). LEDU is responsible for encouraging small firms to play an effective part in strengthening the economy of Northern Ireland and had a budget of $£ 31.3 \mathrm{~m}$ in 1995-96. (Department of Finance and Personnel, H.M. Treasury, 1995). The IDB aims to introduce and develop internationally competitive companies in the manufacturing and tradeable service sectors and spent $£ 135 \mathrm{~m}$ in 1995-96. Put in perspective, expenditure by both central economic development agencies represents about 75 per cent of the total budgets for all 26 district councils.

Since 1992, however (under article 28 of the Local Government (Miscellaneous Provisions) (NI) Order 1992), councils have been permitted to spend up to $5 \mathrm{p}$ in the pound from rates for the specific purpose of economic development. For the year 1995/96 this amounted to $£ 9 m$ spending overall by the councils (Department of the Environment (NI), 1997). Clearly this is insignificant when compared with the budgets of government agencies, but councils have been energetic in its usage. They have embraced the function of economic development enthusiastically, put party differences aside and committed themselves to the welfare and employment prosperity of their council areas. The more innovative have established extensive networks with private companies, set up arms-length enterprise development facilities and used their limited resources as seedcorn finance or matching grants to tap into larger EC funding sources. A recent review of councils' involvement in this functional area cautioned against the fragmentation of the economic development effort, given the number of agencies involved, but also highlighted two key advantages arising from their role. First, local authorities acted as 'a co-ordinator of local efforts and mediator between regional agencies and local communities' and, second, their potential to lever substantial funds from other sources, by a factor of 25 times in the case of Fermanagh District Council (Scott and Hoyle, 1996: 231).

\section{Community Development/Community Relations}

The increasing prominence of councils in economic development as a function has been paralleled by their involvement in the field of community relations. Community development work pre-dates the involvement of councils with cross-community groups under the umbrella of community relations. A number of councils seized the opportunity at an early stage to invest (with government assistance) in community development policies at grassroots level. In 1989 the Central Community Relations Unit (CCRU) ${ }^{3}$ invited councils to participate in a community relations programme aimed at developing cross-community contact and co-operation, promoting greater 
mutual understanding and increasing respect for different cultural traditions. The CCRU offered 75 per cent grant-aid for the employment of community relations staff by councils, the provision of financial support for appropriate cross-community activities, and assistance with the development of local heritage and cultural activities. The 1995/96 CCRU budget for the programme was $£ 1.7 \mathrm{~m}$, matched by a 25 per cent addition from councils.

Councils responded to the CCRU invitation with varying degrees of enthusiasm. The first council (Dungannon) joined the scheme in February 1990 but it was not until 1993 that all 26 local authorities were involved in the initiative which, at the outset, received funding for three years (Belfast City Council has since detached itself following some internal problems).

Despite the staggered starting pattern of councils, the inexperience of newly appointed community relations officers and the scope of the task, funding sources were renewed and the programme subsequently extended until 1998 following a favourable evaluation (Knox et al., 1994). Given the conditions associated with joining the initiative (for example, agreement on a cross-party basis to participate), vesting responsibility for community relations in local councils was, from a government perspective a way of promoting consensus at the political level and in turn, by example, in the community. The community relations remit put consensus firmly on the policy agenda of councils, which is symbolically important in making progress on the wider political front. Moreover, an active involvement in this area, given their chequered history of discrimination and sectarianism, has added to the emerging climate of cross-party co-operation and stability, within which local authorities have demonstrated a more responsible approach to an incremental increase in devolved powers.

\section{Compulsory Competitive Tendering/'Best Value'}

Aside from the new functional responsibilities discussed above, local authorities in Northern Ireland have been preoccupied with compulsory competitive tendering of their services. The process began with a consultative document published by the Department of the Environment (NI) in 1988 on competition in the provision of district council services. Following consultation, which attracted widespread but ineffective crossparty opposition, a draft Miscellaneous Provisions Order was published in 1990. The Order was analogous to, and a direct transfer of, the principal elements of the Local Government Act 1988 applied in Great Britain. Despite initial predictions that CCT would not apply to the limited functions of local government in Northern Ireland, in much the same way as councils had 'escaped' the community charge and council tax reforms, it became a reality in April 1994 for its phased application to council services.

Early assessments of CCT indicate that all 26 councils' contracts were 
won by their in-house direct service organisation (DSO) teams. Further, in all cases the DSO bid was the lowest received. Estimates of savings vary from 2-5 per cent (Chief Executives' Forum, 1996) to 25 per cent (Knox and Young, 1995) for the first round of contract services tendered. These short-term savings are of course influenced by significant start-up costs associated with CCT, such as contract specification and client/contractor organisational restructuring with concomitant staffing implications.

Two considerations are important in assessing the experience of councils in Northern Ireland with CCT - the prevailing economic and political circumstances respectively. The evidence emerging would suggest that small local authority units which exist are unlikely to provide private contractors with the necessary economies of scale. Further, complementarity in services such as refuse collection, street cleaning and grounds maintenance will put councils at an advantage in single contract competition. Both conditions are likely to limit competition in the market which has been the experience thus far. Competition would require multifunctional contracts (refuse, street cleaning and grounds maintenance) offered in no more than four or five areas covering the whole of Northern Ireland (the four existing health board areas would seem sensible). Such a suggestion, however, carries with it huge political implications for local government and questions the very existence of 26 relatively small district councils. Even within present arrangements, the idea of the 'contract council' meeting to allocate their limited functions to the lowest bidder serves only to exacerbate the perception that councillors in Northern Ireland are becoming more marginalised, isolated and impotent. To some extent the success of in-house bidders thus far has forestalled a political backlash on the application of CCT.

With the advent of a Labour ministerial team in Northern Ireland, following the 1997 Westminster elections, the concept of 'best value' will be extended to district councils. This has resulted in an extension of the timetable to tender (for the first time) leisure services, construction and maintenance work until November 1998, so that changes envisaged under 'best value' can be taken on board.

\section{Local Government Finance}

The final issue of general significance to councils is the way in which local authority services are financed. At present this is based on a property tax system or rates, similar to that which operated in Britain prior to the introduction of the poll tax. The tax base is the rentable value of the property (residential and businesses) or its net annual value. Two rates of property taxation are levied, the district rate which is set by each local authority for services provided by them, and the regional rate fixed by central 
government. The latter represents a payment towards the provision of education, housing, personal social services, roads, water and sewerage, referred to as 'local authority type services'. The regional rate is set at a uniform level throughout Northern Ireland and is effectively a central government tax. Both rates are collected by central government and the product of the district rate repaid to local authorities.

Councils have three main sources of funding - the district rate, a general grant and specific government grants ( 78 per cent, 18 per cent and four per cent respectively in the 1996/97 budget estimates). The specific grants are a proportion of approved expenditure for certain functions (for example, community services) and are relatively small in nature. The general grant is the principal grant towards the relief of rate income which takes account of (a) loss of rate income arising from industrial de-rating and (b) a resources element to help poorer councils afford a standard of service without the need to levy excessive rate poundage (Barnett and Knox, 1992).

A report by the Comptroller and Auditor General highlighted three major weaknesses in this system of financing local government (Northern Ireland Audit Office, 1991). First, since the resources element of the general grant is linked to the net expenditure of a council, increases in expenditure increase its share of the grant. Second, the variable needs of the individual councils are ignored in arriving at the percentage grant contribution to net expenditure. There is an absence of any needs assessment. Finally, the Comptroller outlined the main requirement for local accountability: 'a clear and understandable relationship between local authorities' spending decisions and the rate poundages they levy', and asked the Department of the Environment to demonstrate this relationship (Northern Ireland Audit Office, 1991:75). The department pointed to council procedures for examining and approving estimates prior to setting the district rate, but was unable to illustrate the causal link required.

Accountability in the Northern Ireland system is most obvious at both political and financial levels. The regional/district rates split suggests political accountability vested in central and local governments respectively. This, however, is problematic. The district rate represents approximately one-third of the total rate poundage and the remainder is the regional rate for 'local authority-type' services. Since both rates are collected together, the public perception of councils is not one of selective political accountability for spending its portion of the rates but an overall responsibility for finance derived from rates. Local councillors object vehemently to a system in which the efficient provision of district services is nullified by a regional layer of services over which they have no control and whose costs account for an increasing proportion of the total rates bill. The system of financing local government services is currently under 
review and a report is expected soon which addresses these fundamental problems.

\section{FUTURE POSSIBILITIES}

There have been calls both for greater devolution of power to local government and a new form of regional government. In the former case, Archbishop Eames, Church of Ireland Primate, in his submission to the Opsahl Commission ${ }^{4}$ argued for more power to be given to local councils where there was evidence of a sharing of responsibility. This, in his view, would be part of a more systematic progression which entailed 'slow, steady progress in building up inter-community confidence and trust' (Eames, 1993:4). In the latter, Sir Kenneth Bloomfield, former head of the Northern Ireland Civil Service, suggested a review in the form of Macrory II. Both alternatives envisage a greater role for local government but acknowledge that effective safeguards must exist to guard against abuses of power and allay the fear of nationalists.

Notwithstanding these developments, local authorities have now become major brokers in partnership arrangements designed to deliver European-funded service programmes. Partnerships, of course, are neither a new administrative mechanism nor a panacea for the 'democratic deficit'. Partnership formation is now well established in Great Britain as an approach to local area-based economic regeneration and is synonymous with policy initiatives such as Urban Development Corporations, the City Challenge, the Single Regeneration Budget, Training and Enterprise Councils and Business Links (Bailey, 1994). The most recent example in Northern Ireland is the Special Programme for Peace and Reconciliation and the Border Counties (1995), a $£ 350 \mathrm{~m}$ EC package designed to reinforce progress towards a peaceful and stable society and to promote reconciliation (Commission of European Communities Office, 1995). Approximately 15 per cent of the monies available has been allocated to partnerships as a means of harnessing the energies and talents of the local community. Each district council area is represented by a partnership comprising one-third each, local councillors; community/voluntary representatives; business and trades union interests; as well as statutory organisations. The district partnership bids against an allocation for their area (based on population size weighted by an index of deprivation) through a plan of action drawn up to advance the aims and objectives of the initiative. Local authorities have been very successful in operationalising these partnership arrangements despite some early suspicions that the voluntary and business sectors would usurp the role of elected representatives. In a public administration system characterised so completely by government appointees (the most recent 
figures in Northern Ireland suggest there are 161 appointed executive quangos, 38 advisory bodies and 15 tribunals) (Weir, 1994), partnerships at the very least go some way towards representativeness and transparency in decision taking and resource allocation. In short, partnerships have harnessed the emerging goodwill in local authorities, mobilised an apathetic business sector into taking ownership of social goals and energised the voluntary sector which has played a vital role in community development. Faced with a constitutional impasse, local authorities have acted, and can in the future act, as a pivotal broker in partnership arrangements for delivering public services.

There seems little doubt that the future role of local authorities will be central to the administrative reorganisation accompanying any constitutional agreement. What form councils will take is difficult to predict, although it is unlikely that the equivalent unitary status reforms in Great Britain will be replicated (Boyne, Jordan and McVicar, 1995). It is also unlikely that 26 councils will be retained in Northern Ireland, not least because of the efficiency arguments referred to in relation to discussions on CCT/'best value' above. Either four or five large councils co-terminous with health or education board areas seemed possible at one stage. With current proposals to reorganise the education sector and reduce the number of boards, however, this now appears less likely. Developments elsewhere in the public sector, such as the increase in the number of 'Next Steps' agencies, particularly in the Department of the Environment (NI), makes any future reshuffle of functions impossible to predict. Services which may have been considered as possible candidates for devolution to larger councils (for example, planning and minor roads) have been agentised. Whether this makes it more or less difficult to increase the role of local councils is in question.

The Labour minister responsible for local government in Northern Ireland, Lord Dubs, has announced a number of initiatives since taking office. He suggested the possibility of legislation to give councils 'a power of general competence' to do what they consider appropriate in the interests of their district and its people. Other initiatives include proposals to achieve greater representation of councillors on public bodies, and fuller and more meaningful consultation with district councils by central government, particularly in planning, through the establishment of a planning advisory board. These initiatives, he believes, 'will have a positive effect and will serve to strengthen the position of local government and local governance in the Province' (Dubs, 1997).

Local authorities in Northern Ireland have emerged from an era characterised by discrimination and sectarianism. A new climate of cooperation now exists between political parties clearly manifest in the 
additional functions which they undertake. 'Responsibility sharing' arrangements, the common goal of economic development and councils' pivotal role in partnership arrangements for EC-funded initiatives, have created a measure of stability and replaced most partisan wrangling and the tumultuous council meetings synonymous with local government in Northern Ireland. Local politicians, rooted in communities, may reflect more accurately the desired bottom-up momentum for accommodation which has thus far eluded political leaders at the macro-level. It is perhaps ironic, therefore, that local government, whose activities led, in part, to civil rights protests in the late 1960 s, now serve as an example of political cooperation sadly lacking in the current search for a constitutional settlement.

\section{NOTES}

1. 'Sinn Fein and Local Elections: The Government's Response in Northern Ireland', Parliamentary Affairs Vol.43, No.4 (1990), pp.448-63.

2. Some councils - Down, Omagh, Newry and Mourne, claim to have been doing this for years in a less high-profile manner.

3. CCRU is a dedicated unit established within the central secretariat charged with formulating, reviewing and challenging policy throughout the government system with the aim of improving community relations.

4. The Opsahl Commission was a forum established in February 1993 to elicit community views on the way forward in Northern Ireland.

\section{REFERENCES}

Bailey, N., 1994, 'Towards a Research Agenda in Public-Private Partnerships in the 1990s', Local Economy, Vol.8, No.4, pp.293-9.

Barnett, R. and C. Knox, 1992, 'Accountability and Local Budgetary Policy: Unitary Principles?', Policy and Politics, Vol.20, No.4, pp.265-76.

Beirne, M., 1993, 'Out of the Bearpit', Fortnight (May).

Boyne, G., G. Jordan and M. McVicar, 1995, Local Government Reform: A Review of the Process in Scotland and Wales (London: LGC Communications/Joseph Rowntree Foundation).

Chief Executives' Forum/CIPFA, 1996, An Overview of CCT and Market Testing (Belfast: Chief Executives' Forum).

Commission of the European Communities Office In Northern Ireland, 1995, 'Special Support Programme for Peace and Reconciliation in Northern Ireland and the Border Counties of Ireland 1995-99', Eurolink Supplement 9 (Belfast: EC Office).

Connolly, M. and C. Knox, 1986, 'A Review of the 1985 Local Government Elections in Northern Ireland', Local Government Studies, Vol.12, No.2, pp.15-29.

Connolly, M. and C. Knox, 1988, 'Recent Political Difficulties of Local Government in Northern Ireland', Policy and Politics, Vol.16, No.2, pp.89-97.

Department of the Environment for Northern Ireland (Local Government Branch), 1997, District Council (NI) Rate Statistics Tables 1997/98 (Belfast: DoE).

Department of Finance and Personnel/H.M. Treasury, 1995, Northern Ireland Expenditure Plans and Priorities: The Government's Expenditure Plans 1995-96 to 1997-98 Cmd 2816 (London: HMSO).

Dubs Lord, 1997, Ministerial address to SOLACE Conference, Belfast: Waterfront Hall (17 June). 
Eames, R., 1993, 'Ruthless Loyalists', Belfast Newsletter (18 Jan.).

Fitzgerald, M., 1978, 'Northern Ireland: Where is Local Democracy?', Local Government Chronicle, pp.1079-82.

Knox, C., et al., 1994, Community Relations and Local Government (Coleraine: Centre for the Study of Conflict).

Knox, C. and W. Young, 1995, 'Compulsory Competitive Tendering in Northern Ireland Local Government: The End of Round One', Local Government Studies, Vol.21, No.4, pp.591-606.

Macrory Report, 1970, The Report of the Review Body on Local Government in Northern Ireland Cmd 546 (Belfast: HMSO).

Maginness, A., 1990, 'SDLP Warning on Extra Powers', Belfast Telegraph, 12 Jan.

Maginnis, K., 1992, 'Local Democracy in Northern Ireland', in N. Rearden (ed.), Is There Local Democracy North or South? (Kildare: Social Study Conference).

Northern Ireland Audit Office, 1991, Economy, Efficiency and Effectiveness: Examination of Certain Matters (Belfast: HMSO).

Scott, R. and K. Hoye, 1996, 'Local Councils' Economic Development Activities', in E. McLaughlin and P. Quirk (eds.), Policy Aspects of Employment Equality in Northern Ireland Vol II (Belfast: Standing Advisory Commission on Human Rights).

Weir, S., 1994, 'Aloof in Quangoland', Fortnight 335, pp.23-5.

Whyte, J., 1990, Interpreting Northern Ireland (Oxford: Clarendon Press). 